Research Article

\title{
The prediction of Prostate Cancer Based on Normal Digital Rectal Examination and Normal Prostate Specific Antigen in Clinical Benign Prostate Hyperplasia
}

\author{
Zuhirman Zamzami
}

Department of Surgery, Urology Division, Faculty of Medicine University of Riau Pekanbaru, Indonesia

\begin{abstract}
:
Purpose: To evaluate the prediction of prostate cancer based on normal digital examination (DRE) and normal prostate specific antigen (PSA) in clinical Benign Prostate Hyperplasia.

Materials and Methods: We reviewed medical records of prostate cancer in prostate enlargement patients with urinary retension underwent transurethral resection of the prostate (TURP) based on normal DRE, and normal PSA in Arifin Achmad Regional General Hospital, Pekanbaru, Riau Province, Indonesia in January 2010 - Desember 2016. Statistical analysis of univariate was used. Approval on the study was obtained from the Ethical Review Board for Medicine and Health Research, Medical Faculty, University of Riau.

Results: There were 644 prostate enlargement patients with urinary retension underwent TURP) in this study in which mostly (51\%) in 60-69 year age group, Most (69.7\%) DRE were normal and PSA levels of $\leq 4 \mathrm{ng} / \mathrm{ml}$ were in 122 (19\%) patients. There were $19(\mathbf{1 8 . 5 \%})$ prostate cancer in patients with normal DRE and PSA.

Conclusion: We found there were $19(18.5 \%)$ prostate cancers in prostate enlargement patients with normal DRE and PSA findings as the prediction.
\end{abstract}

Keywords: Prediction, Rectal Toucher, Prostate Specific Antigen, Transurethral Resection of the Prostate, Prostate Cancer

\section{INTRODUCTION}

Prostate cancer is a prostate gland malignant tumor suffering men over 50 year in which $75 \%$ were found in 80 year old men and $30 \%$ in 70 year old men [1]. Prosate cancer was the second most malignancy in men after lung cancer [2]. In 2004 in The United States of America 230.110 prostate cancer patients were found. Prostate cancer was often found in AfroAmerica and the black skin was more than the white one [1]. Prostate cancer in Indonesia was the the most malignancy in urology clinic and 2006-2010 there were 971 cases [4]. A study by Yuwinanda (2008) din Arifin Achmad Regional General Hospital Pekanbaru Riau Province, prostat cancer was the third malignancy of 12 malignancies in urology [4].

High incidence of prostate cancer cases in Indonesia indicated the demand of diagnostic and prognostic parameters of prostate cancer such as yaitu Prostate Specific Antigent (PSA) (5). PSA is a marker of malignancy process correlating positively to prostate cancer [6]. PSA role in prostate enlargement is improving sel tumor cell proliferation through the function as coactivator for increasing Androgen Reseptor (AR) in which highly influencing on the prostate growth. The increase of serum PSA level has become an important marker of several prostat diseases is not only found in prostate cancer but can also found in Benign Prostate Hyperplasia (BPH) [7].

Benign Prostate Hyperplasia is a prostate enlargement in which can cause posterior urethral narrowing adalah penyakit pembesaran prostat yang dapat menyebabkan penyempitan urethra posterior [1]. Although it seldom cause life threatening, BPH symptoms result in disturbance of daily activities, and the prostate enlargement process occurs slowly. Transurethral Resection of the Prostate (TURP) is a most effective and gold standart management of indicated BPH [8]. The success rate of TURP in overcoming the clinical symptoms due to BPH was $88 \%$ [9].

Many studies on PSA levels of prostate before TURP had been published. Study on normal digital rectal and normal PSA level in clinical BPH patients underwent and in fact the histopathology findings were prostate cancer had been published yet. That was why, according to the above data we aimed to conduct a study on evaluating the prediction of prostate cancer based on and normal PSA) in clinical Benign Prostate Hyperplasia.

\section{MATERIALS AND METHODS}

We reviewed medical records of prostate cancer in prostate enlargement patients with urinary retension underwent TURP based on normal DRE, and normal PSA in Arifin Achmad Regional General Hospital, Pekanbaru, Riau Province, Indonesia in January 2010 - Desember 2016. Statistical analysis of univariate was used. Approval on the study was 
Zuhirman Zamzami / The prediction of Prostate Cancer Based on Normal Digital Rectal Examination and Normal Prostate Specific Antigen in Clinical Benign Prostate Hyperplasia

obtained from the Ethical Review Board for Medicine and Health Research, Medical Faculty, University of Riau.

\section{RESULT}

There were 644 prostate enlargement with urinary retension patients underwent TURP in Arifin Achmad Regional General Hospital, Pekanbaru, Riau Province fulfilled the inclusion criteria during seven year in January 2010 December 2016.

\section{DISCUSSION}

There were 644 prostate enlargement with urinary retension patients underwent TURP in Arifin Achmad Regional General Hospital, Pekanbaru, Riau Province fulfilled the inclusion criteria during seven year in January 2010 December 2016. This study showed that the most age group of prostate enlargement cases with urinary retension was 60-69 year namely 21 (50\%) patients while the less one were 40-49 year and $\geq 80$ year namely 31 (4.8\%) patient (See in Table 1$)$. Some studies PCa occurred in younger patients $(<60$ years) and to dissipate in older groups (> 70 years)

Table 1. Frequency distribution of age in prostate enlargement with urinary retension patients underwent TURP in Arifin Achmad Regional General Hospital, Pekanbaru, Riau Province in January 2010 - December 2016.

\begin{tabular}{lll}
\hline Age (year) & Frequency $(\mathbf{N})$ & Percentage $(\boldsymbol{\%})$ \\
\hline $40-49$ & 31 & 4.8 \\
$50-59$ & 122 & 19.0 \\
$60-69$ & 322 & 50.0 \\
$70-79$ & 138 & 21.4 \\
$\geq 80$ & 31 & 4.8 \\
\hline Total & $\mathbf{6 4 4}$ & $\mathbf{1 0 0}$ \\
\hline
\end{tabular}

This study showed DRE findings in prostate enlargement patients with urinary retension before TURP were mostly normal namely $441(69.7 \%)$ patients while the less one abnormal namely 197 (30.6\%) patients (See in Table 2).

Table 2. Frequency distribution of digital rectal examination (DRE) in prostate enlargement with urinary retension patients underwent TURP in Arifin Achmad Regional General Hospital, Pekanbaru, Riau Province in January 2010 December 2016.

\begin{tabular}{lll}
\hline DRE & Frequency $(\mathbf{N})$ & Percentage $(\boldsymbol{\%})$ \\
\hline Normal & 447 & 69.7 \\
Abnormal & 197 & 30.6 \\
Total & 644 & 100 \\
\end{tabular}

This study showed that in prostate enlargement patients with urinary retension before TURP, PSA levels were mostly 4.1 $10 \mathrm{ng} / \mathrm{ml}$ namely 291 (45.2\%) patients followed by > $20 \mathrm{ng} / \mathrm{ml}$ namely $184(28.6 \%)$ patients and $\leq 4 \mathrm{ng} / \mathrm{ml}$ namly $122(19 \%)$ pasien (See in Table 3).
Table 3. Frequency distribution of PSA levels in prostate enlargement with urinary retension patients underwent TURP in Arifin Achmad Regional General Hospital, Pekanbaru, Riau Province in January 2010 - December 2016.

\begin{tabular}{lll}
\hline PSA $(\mathbf{n g} / \mathbf{m l})$ & Frequency $(\mathbf{N})$ & Percentage $(\%)$ \\
\hline$\leq 2$ & 61 & 9.5 \\
$2.1-4$ & 61 & 9.5 \\
$4.1-10$ & 291 & 4.2 \\
$10.1-20$ & 46 & 7.1 \\
$>20$ & 184 & 28.6 \\
\hline Total & $\mathbf{6 4 4}$ & $\mathbf{1 0 0}$ \\
\hline
\end{tabular}

This study showed histopathology findings in prostate enlargement patients with urinary retension underwent TURP were mostly BPH namely 541 (84\%) patients while PCa were $103(16 \%)$ patients (See in Table 4).

Table 4. Frequency distribution of histopathology in prostate enlargement with urinary retension patients underwent TURP in Arifin Achmad Regional General Hospital, Pekanbaru, Riau Province in January 2010 - December 2016.

\begin{tabular}{lll}
\hline Histopathology & Frequency $(\mathbf{N})$ & Percentage $(\%)$ \\
\hline BPH & 541 & 84.0 \\
Carsinoma Prostat & 103 & 16.0 \\
\hline Total & $\mathbf{6 4 4}$ & $\mathbf{1 0 0}$
\end{tabular}

This study showed bone scan findings in in prostate enlargement patients with urinary retension underwent TURP were mostly negative metastasis namely 59 (57.3\%) patients while positive metastasis namely 44 (47.7) patients (See in Table 5).

Table 5. Frequency distribution of bone scan findings in prostate enlargement with urinary retension patients underwent TURP in Arifin Achmad Regional General Hospital, Pekanbaru, Riau Province in January 2010 December 2016.

\begin{tabular}{lcc}
\hline $\begin{array}{l}\text { Bone } \\
\text { findings }\end{array}$ & Scan requency $(\mathbf{N})$ & Percentage (\%) \\
\hline Metastasis (-) & 7 & 57.3 \\
Metastasis (+) & 7 & 47.7 \\
Total & 33 & 100 \\
\hline
\end{tabular}

This study showed PCa stages in prostate enlargement patients with urinary retension underwent TURP were mostly local stage namely $59(57.3 \%)$ patients while anvanced stage namely $44(47.7 \%)$ patients (See in Table 6).

Table 6. Frequency distribution prostate cancer (PCa) stage in prostate enlargement with urinary retension patients underwent TURP in Arifin Achmad Regional General Hospital, Pekanbaru, Riau Province in January 2010 - 
Zuhirman Zamzami / The prediction of Prostate Cancer Based on Normal Digital Rectal Examination and Normal Prostate Specific Antigen in Clinical Benign Prostate Hyperplasia

December 2016.

\begin{tabular}{lll}
\hline CaP & Frequency $(\mathbf{N})$ & Percentage $(\%)$ \\
\hline Local stage & 59 & 59.5 \\
Advanced stage & 44 & 40.5 \\
\hline Jumlah & $\mathbf{1 0 3}$ & $\mathbf{1 0 0}$ \\
\hline
\end{tabular}

This study showed CaP in clinical BPH without PCa signs in prostate enlargement patients with urinary retension underwent TURP were PCa in which were clinical PCa before TURP namely $84(81.5 \%)$ patients while $\mathrm{PCa}$ in which clinical BPH before TURP namely $19(\mathbf{1 8 , 5 \%})$ patients, and this was prediction of PCa in clinical BPH TURP (See in Table 7). This prediction was higher than the one of a study by Thomson (2004) namely $15.2 \%$ [11].

Table 7. Frequency distribution of $\mathrm{PCa}$ in clinical $\mathrm{BPH}$ without clinical $\mathrm{PCa}$ in prostate enlargement with urinary retension patients underwent TURP in Arifin Achmad Regional General Hospital, Pekanbaru, Riau Province in January 2010 - December 2016.

\begin{tabular}{lll}
\hline CaP & Frequency $(\mathbf{N})$ & Percentage (\%) \\
\hline $\begin{array}{l}\text { Clincal BPH } \\
\text { before TURP }\end{array}$ & 19 & 18.5 \\
$\begin{array}{l}\text { Clinical CaP } \\
\text { before TURP }\end{array}$ & 84 & 81.5 \\
\hline Jumlah & $\mathbf{1 0 3}$ & $\mathbf{1 0 0}$ \\
\hline
\end{tabular}

This study showed PCa stages in clinical BPH without signs of $\mathrm{PCa}$ in prostate enlargement patients with urinary retension underwent TURP were PCa which were clinical PCa before TURP mostly the advanced stage namely 15 (79\%) patients while PCa which were clinical BPH before TURP were lesser namely local stage in 4 (21\%) patients (See in Table 8).

Table 8. Frequency distrbution of $\mathrm{PCa}$ stage in clinical BPH without clinical $\mathrm{PCa}$ in prostate enlargement with urinary retension patients underwent TURP in Arifin Achmad Regional General Hospital, Pekanbaru, Riau Province in January 2010 - December 2016.

\begin{tabular}{lll}
\hline $\begin{array}{l}\text { CaP dg } \\
\text { Klinis }\end{array}$ & FPHekuensi (N) & Persentase (\%) \\
\hline Local stage & 4 & 21 \\
Advanced stage & 15 & 79 \\
\hline Jumlah & $\mathbf{1 9}$ & $\mathbf{1 0 0}$ \\
\hline
\end{tabular}

This study showed local stage $\mathrm{CaP}$ in clinical $\mathrm{BPH}$ without signs of $\mathrm{PCa}$ of all $\mathrm{CaP}$ in prostate enlargement patients with urinary retension underwent TURP mostly local stage PCa in clinical BPH without signs of PCa namely 15 (25.4\%) patients while local stage $\mathrm{PCa}$ in clinical PCa merely 44 (74.6\%) patient of all $\mathrm{PCa}$ in prostate enlargement patients with urinary retension underwent TURP (See in Table 9).

Table 9. Frequency distribution of local stage PCa in clinical $\mathrm{BPH}$ without $\mathrm{PCa}$ of all $\mathrm{PCa}$ in prostate enlargement with urinary retension patients underwent TURP in Arifin Achmad Regional General Hospital, Pekanbaru, Riau Province in January 2010 - December 2016.

\begin{tabular}{lll}
\hline PCa & Frequensi (N) & Percentage (\%) \\
\hline $\begin{array}{l}\text { Local stage in } \\
\text { clinical BPH }\end{array}$ 15 & 25.4 \\
before TURP & & \\
$\begin{array}{l}\text { Local stage in } \\
\text { clinical PCa } 44\end{array}$ & 74.6 \\
before TURP & & \\
\hline Jumlah & $\mathbf{5 9}$ & $\mathbf{1 0 0}$ \\
\hline
\end{tabular}

This study showed advanced stage $\mathrm{PCa}$ in clinical $\mathrm{BPH}$ without signs of $\mathrm{PCa}$ of all $\mathrm{PCa}$ in prostate enlargement patients with urinary retension underwent TURP mostly local stage $\mathrm{PCa}$ in clinical $\mathrm{BPH}$ without signs of PCa namely 4 (9.1\%) patients while local stage PCa in clinical PCa merely $40(90.9 \%)$ patient of all $\mathrm{PCa}$ in prostate enlargement patients with urinary retension underwent TURP (See in Table 10).

Table 10. Frequency distribution of advanced stage $\mathrm{PCa}$ in clinical $\mathrm{BPH}$ without $\mathrm{PCa}$ of all $\mathrm{PCa}$ in prostate enlargement with urinary retension patients underwent TURP in Arifin Achmad Regional General Hospital, Pekanbaru, Riau Province in January 2010 - December 2016.

\begin{tabular}{lll}
\hline PCa & Frequency $(\mathbf{N})$ & Percentage $(\%)$ \\
\hline $\begin{array}{l}\text { Advance stage in } \\
\text { clinical BPH } \\
\text { before TURP }\end{array}$ & 9.1 \\
$\begin{array}{l}\text { Advanced stage } \\
\text { in clinical CaP }\end{array}$ & 40 \\
before TURP & & 90.9 \\
\hline Jumlah & $\mathbf{4 4}$ & $\mathbf{1 0 0}$ \\
\hline
\end{tabular}

\section{CONCLUSION}

Prostate cancer prediction in clinical BPH before TURP were $19(18.5 \%)$ patients in which $15(25.4 \%)$ patients were in local stage and $4(9.1 \%)$ patients were in advanced stage

\section{REFERENCES}

[1] Purnomo B. Prostate cancer. In: Basic Urology $3^{\text {rd }}$ Ed.Jakarta : CV Seagung Seto,2011: 261.

[2] Tambunan N, Umbas R. Role of nutrition factor in preventing prostate cancer. Indonesia Journal of Cancer.2014;8 (3): 1- 3.

[3] Lubis AS, Denarto. Cut off level of prostate specific antigen (PSA) in prostatate cancer patients for producing metastasis to bone in Sardjito Hospital Yogyakarta. Indonesian Journal of Cancer .2014: 8(4). 3-5

[4] Yuwinanda DP, Zuhirman. Profile of urologic malignancy in Arifin Achmad Regional General Hospital Pekanbaru, Riau Province January 2006-December 2009.2011. [Scipsy]. Pekanbaru: University of Riau.

[5] Agung S. Imunologic Aspec of prostate cancer. Muhammadiyah Journal of Nursing. 2009;24 (8): 6. 
[6] Subrata Sumarno Adi, Kestyaningsih Tri W, Istanti Yuni P. Penyusunan TURP Syndrome Tool Assesment.2009. Muhammadiyah Journal of Nursing. 2009;24 (8): 18.

[7] Hidayah S, Nurlela S. Correlation tumor associatedmacrophages (TAMs), microvessel density (MVD), prostat specific antigen (PSA) between histology grading of high grade PIN and prostate adenocarsinoma.[Thesis] .2014.Jogyakarta.Gajah Mada University.

[8] Dewi S, Widnyana M G, Suranadi W. The difference of blood osmolality and blood $\mathrm{pH}$ in TURP administered with hypertonic sodium lactate $3 \mathrm{ml} / \mathrm{kg}$ and $0,9 \%$ sodium chloride 3 ml/kg. Jurnal Ilmiah Kedokteran. 2013; 44 (3): 158-159

[9] Madjid, Irawaty D, Nuraini T. Decreasing patient's dribbling symptoms after transurethral resection of the prostate through Kegels exercise. Journal Keperawatan Indonesia.2011; 14 (2) 14.

[10] Cheng I, Witte JS, McClure LA, et al. Socioeconomic status and prostate cancer incidence and mortality rate among the diverse population of California. Cancer Causes Control.2009;20(8):1431-40.

[11] Thompson IM, Pauler DK, Goodman PJ, et al. Prevalence of prostate cancer among men with a preostate-spesific antigen level < or $=4 \mathrm{ng}$ per milliliter. $\mathrm{N}$ Eng $\mathrm{J}$ Med.2004;350(22):2239-46 